\title{
A Sensory-Based Program for Developing EFL Majors' Sensory Vocabulary Knowledge and Descriptive Writing Performance
}

Mohamed Farrag Ahmed Badawi, PhD

Associate Professor of Curriculum \& EFL Instruction

Faculty of Education, October 6 University, Egypt

\section{Abstract}

The study was an attempt to investigate the effectiveness of a suggested sensory based program in developing first year university EFL majors' sensory vocabulary knowledge and descriptive writing performance. The study participants were 84 first year students majoring in English language at the Faculty of Education, October 6 University, Egypt. The participants were randomly divided into two equal groups. To collect the data, a sensory based program, a sensory vocabulary knowledge test, and a descriptive writing performance test were designed and implemented. Before the intervention, all the participants were pretested. While the experimental group participants $(n=42)$ were exposed to the sensory based program, the control group participants $(n=42)$ received their regular writing instruction. Results revealed that the sensory based program was more effective than regular writing classes in developing EFL students' sensory vocabulary knowledge. Similarly, the sensory based program was effective in developing EFL students' descriptive writing performance. Based on the study results, it was recommended that using senses in teaching/learning writing genre in EFL contexts should be adopted as an effective and attractive pedagogy.

Keywords: Sensory Program, Sensory Vocabulary, Descriptive Writing, EFL Students.

\section{Introduction}

Writing is an important part of English language skills. To be able to write, EFL students should learn how to write. In actuality, the ability to write is a vital skill for both foreign language learners as much as for first language learners. Accordingly, teaching writing has been recognized as an essential component of first and foreign English language literacy programs. In EFL contexts, mastering writing skill is necessary for EFL majors to write reports, term papers, assignments and examinations.

\section{7}

Journal of Arabic Studies in Education \& Psychology(ASEP) 
Writing is a prerequisite for success in academic arenas. Hosseni, Taghizedeh, Abedin and Naseri (2013) remark that there is a significant correlation between EFL students' content subject scores and their writing skills. Hussin et al., (2015) mentions that writing is a survival skill as learners are obliged to use it as a medium for learning content courses. Harmer (2004, p. 245) argues that "language learners are called successful when they are able to use the language in a good written form." Based on these remarks, it could be stated that writing skill is crucial for EFL university majors because a great deal of their academic achievement is tested through writing performance. Simply, for EFL students' writing proficiency level is one of the key factors that could affect their academic and professional success. Thus, writing courses in higher education institutions should receive the same importance and care given to the content courses.

However, most of the writing performance of EFL students majoring in English language seems inadequate. To exemplify, Alagozlu (2007, p.120) mentions that most of EFL students "cannot express their own ideas in EFL writing." Therefore, mastering writing is the most challenging language skill for EFL students. To this point, Alwasilah (2001) remarks that writing is the most neglected subject and it is the most difficult language skill to be learnt by students and to be taught by teachers as well. Myles (2002) claims that most students in EFL/ESL writing classes hate writing. For Hiew (2012), the skill of writing is said to be a skill which EFL students are less proficient in. Accordingly, writing difficulty and hate are subject to be increased when EFL students are required to write on a specific genre.

Genre writing is a type of writing that conveys a specific purpose using certain rhetorical patterns. Among

\section{8}


the common writing genres is descriptive writing. Descriptive writing genre has its own rhetorical patterns, conventions and vocabularies. Sumarsih and Sanjaya (2013, p. 108) define descriptive writing as "a paragraph [a piece of writing] that describes a particular person, place or event in great detail. Mainly, descriptive writing colorfully portrays something in a way [that] enables the readers visualize it and go through the writer's experience or imagination." To comply with the rhetorical conventions of descriptive writing, EFL majors have to be keen to certain specific sensory details to describe what is seen, heard, touched, tasted, and smelled.

The previously mentioned brief review reveals the paradox that while most of EFL university students lack the sufficient knowledge and the skills of the rhetorical patterns of genre writing, they have to produce quality writing genre to pass the exams of the assigned content courses. Responding to the current situation, EFL university students should to be trained on the rhetorical conventions of descriptive writing as well as the basic sensory descriptive vocabulary to improve their writing performance and in turn they can meet the requirements of studying English language as a major.

\section{Context of the Problem}

Previous research indicates that EFL majors' writing performance is satisfactory. Moreover, it represents one of the nagging problems in EFL research (Mason, Harris, and Graham, 2011). Furthermore, Alwasilah (2001) mentions that writing is the most neglected subject in EFL context and it is the most difficult language skill to be learnt by students and to be taught by a teacher. Moreover, Myles (2002) claims that most students in EFL/ESL writing classes hate writing because they have difficulties in getting

\section{9}


started, finding the right words, and developing topics when they begin to write and express their ideas. Finally, Wang (2004, p. 24) asserts that teaching EFL writing is a headache for many teachers; despite their considerable efforts in correcting their students' compositions, many students' written English "remains non-idiomatic, poorly organized, insufficiently developed, grammatically awkward, devoid of sentence structure variety, and weak in vocabulary usage."

As a faculty member at October 6 University, the researcher noticed that the writing performance of the majority of first year EFL majors at the Faculty of Education (academic year 2016-2017) is not up to the that performance required for studying EFL as an academic major. That is why they confront difficulties when they are asked to write on a specific writing genre such as descriptive, argumentative, and narrative paragraphs. Backing his personal observation, the researcher asked the first year EFL majors to voluntarily write a descriptive piece of writing on a topic they like most. The test was carried out during one of the regular writing classes in the academic year (2015-2016). While 46 students completed the voluntary writing exam, 21 students left the voluntary exam session once they were informed that the exam has nothing to do with their credited course results. The voluntary writing exam results displayed that $86 \%$ of the test takers committed the same common linguistic and genre rhetorical mistakes. Such result goes in line with Fitri (2013: 74) who states that the four common problems in writing are content, organizing, vocabulary and grammar.

\section{Statement of the Problem}

The writing performance of the EFL first year students majoring in English language at the Faculty of Education, October 6 University is not up the level required

\section{0}


as they face difficulties when they write on a specific writing genre such as descriptive paragraphs. Therefore, the current study is concerned with developing EFL first year English majors' sensory vocabulary knowledge and descriptive writing performance via a suggested sensorybased program.

\section{Questions of the Study}

The study attempts to answer the following questions:

1. To what extent do EFL first year English majors possess sensory vocabulary knowledge?

2. To what extent is the suggested sensory based program effective in developing EFL first year English majors' sensory vocabulary knowledge?

3. What is the effect size of the suggested sensory based program on developing EFL first year English majors' sensory vocabulary knowledge

4. To what extent do EFL first year English majors possess descriptive writing rhetorical patterns?

5. To what extent is the suggested sensory based program effective in developing EFL first year English majors' descriptive writing performance?

6. What is the effect size of the suggested sensory based program on developing EFL first year English majors' descriptive writing performance?

\section{Hypotheses of the Study}

The study aims at testing the following hypotheses:

1. There is no statistically significant difference between the mean scores of the control group students and the experimental group participants on the sensory vocabulary knowledge test (SVKT) pre-testing.

2. There is a statistically significant difference between the mean scores of the control group students and the

\section{1}


experimental group participants on the SVKT posttesting favoring the experimental group participants.

3. There is a statistically significant difference between the mean scores of the experimental group participants' mean scores on the SVKT pre and posttesting SVKT favoring their mean scores on the SVKT post-testing.

4. There is no statistically significant difference between the mean scores of the control group students and the experimental group participants on the predescriptive writing performance test (DWPT).

5. There is a statistically significant difference between the mean scores of the control group students and the experimental group participants on the DWPT post testing favoring the experimental group participants.

6. There is a statistically significant difference between the mean scores of the experimental group participants' mean scores on the DWPT pre and posttesting favoring their mean scores on the DWPT post testing.

\section{Aim of the Study}

The aim of the current study is to investigate the effectiveness of a suggested sensory based program in developing first year university EFL majors' sensory vocabulary knowledge and descriptive writing performance.

\section{Significance of the Study}

The significance of the present study stems from the claim that writing skill for EFL university students majoring in English language is not only an end, it is also a means for enhancing their academic achievement in content courses. In addition, while a large body of writing research in EFL context focused on developing teaching/learning general writing skills of pre-university students, genre writing

\section{2}


research at university level was marginalized. Accordingly, focusing on genre writing encourages EFL researchers to investigate additional topics in genre writing as a rich area of future research. Moreover, using senses for developing EFL university majors' genre writing performance is assumed to be one of the leading trends in EFL writing research.

\section{Definitions of Terms}

According to the study theoretical background and its practical scope, three basic terms were operationally defined and conceptualized.

\subsection{Sensory Based Program (SBP):}

As an instructional design type, the (SBP) was used in the current study to refer to the possible utilization of the five senses such as sights, sounds, smells, tastes, and textures for designing and delivering the planned and intended training inputs to improve EFL first year tertiary English majors' sensory descriptive vocabulary knowledge and descriptive writing performance.

\subsection{Sensory Vocabulary Knowledge (SVK):}

The term (SVK) was coined and conceptualized to refer to EFL first year tertiary English majors' awareness of the meaning/definition, formation/parts, and positioning/ context of descriptive words. Simply, sensory vocabulary knowledge refers to form, meaning, and use of descriptive words.

\subsection{Descriptive Writing Performance (DWP):}

Sumarsih and Sanjaya (2013, p. 108) agree that descriptive writing is a written text aiming at describing or portraying a person, thing, event or place. Procedurally, the term (DWP) was used to refer to the vivid descriptive paragraphs produced by EFL first year tertiary English majors at October 6 University for describing an object or event using their senses properly.

\section{3}




\section{Study Delimitations}

The findings of the current study should be recognized in light of the following delimitations:

1. The operational definitions of the key terms and variables.

2. EFL first year English majors (First Term, 20162017).

3. Faculty of Education, October 6 University, Egypt.

4. Academic felicities and technical support that were available in the first term 2016-2017.

\section{Review of Literature}

\subsection{Writing in EFL University Context}

Writing skill for higher education students is very important. A great deal of the academic achievement of university English majors is evaluated through writing performance. Writing enables university students to well convey the content knowledge in the formal exams. For Kitchakarn (2012), writing is a tool reflecting EFL learners' understanding of English. Kellogg (2008) clarifies that writing ability marks the literacy of a writer as it is a dual process of generating ideas and putting those ideas into words and paragraphs. Hosseni, Taghizedeh, Abedin and Naseri (2013) mention that the correlation between content score of students and their writing skills is significant. Thus, writing courses should occupy the same position of content courses in higher education programs.

Writing teaching in EFL context remains revolving around process writing versus product writing. While product oriented teaching of writing targets the final product of writing, the process oriented approach to writing is concerned with how a piece of writing is written. Ideally, the teaching of writing should function both process and

\section{4}


product pedagogies. However, Kroll, Diaz-Rico \& Weed (2002) and Jarunthawatcha (2010) claim that the most significant shift in teaching writing is that the focus on writing as a process has become stronger than that of a product.

In spite of this shift, higher education students tend to focus on the end product of writing to carry out their assignments and exams. That is to say, EFL university English majors write to pass their courses with a satisfactory end product. Thaiss and Zawacki (2006) confirm that professors expect to see evidence of tenacity, openness and preparation along with reasonability and rationality in pieces of writing. To conclude, insisting on adopting product writing pedagogy at the expense of process writing pedagogy has encouraged some EFL/ESL researchers to adopt the genre approach as an innovative writing teaching pedagogy.

\subsection{Writing Genre}

Etymologically, the word genre is a French word meaning form or type. According to Hyland (2003), genre becomes a kind of language object to study using Systemic Functional Linguistic as a basic and fundamental framework of the usage of the language in terms of genre. Moreover, Christie (2000) states that genre is the particular usage of the language in a certain social circumstance such as interview genre, media genre, or advertisement genre, and so forth. Hence, the bottom line is that the purpose of text shapes its linguistic and rhetorical features.

Pedagogically, the genre approach emerged as an alternative view of teaching writing. For Hyland (2007), the writing performance of the EFL students who were exposed to a genre-based approach was better than the writing performance of those who were exposed to the process

\section{5}


approach. Cope \& Kalantzis (2012) mention one more advantage of genre approach that is genre approach necessitates that students learn explicitly the language used to make meaning in a text. To this point, Chakraverty and Gautum (2008, p 286) mention that, "writing is essentially a reflective activity that requires enough time to think about the specific topic and to analyze and classify any background knowledge. Then, writers need suitable language to structure these ideas in the form of a coherent discourse." Raoofi et al. (2014) suggest that to improve the writing performance of EFL novice and unskilled writers require motivational, social, cognitive and cultural input before producing the final written product. Therefore, university students should be trained on writing genre that fits the specific nature of the assigned content courses. To conclude, Tardy (2011) suggests that genre pedagogies are useful to meet the writing challenges that EFL students face.

Furthermore, Hyland (2007) mentions that writing genre is a group of texts that share similar rhetorical and structural features to serve a communicative purpose that can be easily identified by members of a certain community. This interpretation rests on Reppen's (1995) assertion of the significance of genre in offering students many chances to comprehend the various purposes of written texts and how to organize the tackled information differently. Pedagogically, Widodo (2006) demonstrates that a genre based approach to teaching EFL writing focuses on the conventions of a particular text type and attempts to help students understand the text purpose, its audience, and its organization.

Moreover, Evans (2013) and Pike (2013) argue that all extended written discourse can be categorized into a set of text types: recount/descriptive, narrative, explanation, information report, procedure, discussion and exposition.

\section{6}


Each one of these different types has a distinctive purpose, audience and features that distinguish it from other types. Besides, Wennerstrom (2003, p.3) emphasizes that "Each genre presents a different set of rhetorical choices from lexicon and grammar to format, content, and organizationthat students can study and adapt to their own writing."

Genre in writing is a part of genre in language use. Thoreau (2006) explains that genre in writing or genre writing is a type of writing in which it has a typical style, particular target of readers, and a specific purpose. Accordingly, it could be said that genre covers three main aspects, namely, writing style, readers, and writing goal. In terms of style, Thoreau adds that writing style means how something is written; the words that are used and the way the information is organized. Scott and Avery (2001) confirm that style in writing is words or expressions used to write the writing and how language patterns are expressed. Generally, genre implies that when students write they write something to achieve some purposes.

In this respect, Cheng (2005), Kim (2006), Kongpetch (2006) and Tardy (2011) have shown that a genre based approach can improve students' writing skills in constructing the different types of texts such as narrative and expository. Moreover, Martin and Rose (2012) notice that genre-based approaches of writing teaching attract considerable interest from language teachers who are looking for suitable frameworks to promote the development of the discourse competence of their learners. According to Badger and White (2000), when the process approach is coupled with the genre approach, students are acquainted with the language features that characterize the type of academic writing expected of them. In short, descriptive writing as a writing genre necessitates that EFL students have to use certain descriptive vocabulary and

\section{7}


comply with the descriptive writing patterns and conventions.

\section{3. Sensory Descriptive Writing}

According to Tilestone (2015), 98\% of all new learning enters the brain through the five senses. In addition, Truscott (2015) argues that second language inputs based on the senses is an essential aspect of language acquisition. Along with this point, Katai (2011) remarks that learning input by means of senses provides equality of opportunities for each student. To reiterate, Katai mentions sensory based learning helps "to recall the stored information easily in the future (p234)." Further, Griva and Semoglou (2012) agree that activities which appeal to the five senses, such as visual, auditory, tactual and kinesthetic and hands-on activities have been reported to be the most effective teaching aids in English language classes.

Therefore, the teaching of descriptive writing in EFL context should make good use of the power of senses. According to Bengu (2015, p 622), "In fact, with descriptive writing you are not developing argument...You are representing the situation as it stands...The most characteristic features of descriptive writing are that it will describe something, but will not go beyond an account of what appears to be there." In practice, in descriptive writing, the writer uses sensory details such as sights, sounds, smells, tastes, feelings, and textures to create vivid images in the reader's mind. An experienced writer relies on sense memories of a specific experience to write a piece of descriptive writing.

There is a consensus among the researchers who defined descriptive writing. Rozmiarck (2000, p. 9) defines descriptive writing as "adequate details to describe a particular topic in such a way to appeal to the audience."

\section{8}


Likewise, Glencoe (2005) mentions that descriptive writing is "to compose an effective description, the writer creates vivid word pictures and organizes these pictures into effective patterns (p. 127)". Moreover, Nazario, Borchers, and Lewis $(2010$, p. 26) state that the goal of description is to convey "an overall idea, or dominant impression, of the topic by building up concrete details to support the general point." Sumarsih and Sanjaya (2013, p. 108) state that descriptive writing is a written text aiming at describing or portraying a person, thing, event or place.

Adding to this, descriptive writers use sensory details such as sights, sounds, smells, tastes, feelings, and textures to create vivid images in the reader's mind. An experienced writer relies on sense memories of a specific experience to summon to mind these details to write a piece of descriptive writing. To describe an object, the writer has to show how this object looks like, how it sounds, how it feels, how it tastes, and how it smells. It is supposed that descriptive paragraphs which depend on writers' senses may enable them to write quality descriptive texts. However, utilizing one's senses needs knowing some basic descriptive words. Pilkulski and Templeton (2004) argue that it is impossible to ignore the power of words. That is why the present study attempted to re-conceptualize vocabulary knowledge as sensory vocabulary knowledge as a core component of descriptive wring.

\section{4. Sensory Vocabulary Knowledge}

Vocabulary knowledge is an essential way for learning a language. Simply, words are the blocks of a language. Recently, the significant effect of vocabulary knowledge on second or foreign language learning has been underlined by Zahedi and Abdi (2012). Gathercole (2006) mentions that vocabulary has a great influence on students'

\section{9}

Journal of Arabic Studies in Education \& Psychology(ASEP) 
proficiency and their production and comprehension of language. Nation (2001) asserts that learning vocabulary items plays a vital role in all language skills in English as a second language and English as a foreign language.

As a brain activity, writing needs memory, accuracy, and skill to combine words in proper linguistics rule (Deporter \& Heracky 2002). It means that in order to convey a message from the writer's thought to the reader through a piece of writing, the writer should utilize the sufficient words and compose them in a proper language rule. Brown (2007) mentions that among the six indicators of writing evaluation is vocabulary or lexis. Accordingly, EFL learners are required to use various relevant vocabularies in their essay, paragraphs or test. To mention one of the radical views of EFL/ESL, Gass (1999, p.123) puts it clearly that "learning a second language means learning its vocabulary."

For Harmon, Wood and Kiser (2009), learning vocabulary is an important instructional aim for EFL teachers in all content areas. Harmer (2007, P. 229) argues that "when teaching vocabulary explain[ing] meaning is a major part of the teacher's art. Students need to see words in context to see how they are used." Besides, Hadfield (2008, P. 46) claims that "it is also necessary to expose students to idioms, collocations and register in order to explain the meaning and use of certain vocabulary in the explicit way.

Mistakenly, vocabulary knowledge is seen as isolated and memorized information about the meanings of particular words. In fact, vocabulary knowledge is beyond this notion (Nagy, 2005). In line with Nagy, Nation (2011) mentions that learners should know which word to use, how and where to use it. This knowledge constructs the aspects of vocabulary knowledge, which are meaning, form, and use

\section{0}

Journal of Arabic Studies in Education \& Psychology(ASEP) 
respectively. Consequently, word meaning, formation and function were the three key components of the proposed conceptualization of sensory vocabulary knowledge.

\section{5. Previous Research}

A number of studies (Al Fadda, 2012; Farooq, Hassan, \& Wahid, 2012; Javid, Farooq, \& Umer 2013; AlKhairy, 2013; Mustaque, 2014; Yuen and Mussa, 2015) focused on identifying writing problems in different EFL contexts. Al Fadda (2012) identified writing problems using a questionnaire offered to 50 post graduate students studying at a university in Saudi Arabia. The study pointed out the problems of use of plague words and phrases, reviewing grammar, use of pronouns, problem of agreement between pronoun and antecedents, subject verb agreement, sentence fragments and difficulty of combining sentences. Farooq, Hassan, \& Wahid (2012) found the problems of vocabulary, grammar and spelling as the problems of the $12^{\text {th }}$ graders studying in Pakistan. In addition, the study reported that using comma and L1 interference were common problems in students' English writing performance. The study of Javid, Farooq, \& Umer (2013) revealed that the problem of organization in addition to problems of vocabulary and grammar problems. Mustaque (2014) found that the problems of grammar, vocabulary and organization were the common mistakes of Bangladesh university students. Yuen and Mussa (2015) found language problems and organization problems through the responses of the questionnaires completed by 30 post-graduate Iraqi learners studying at a university in Malaysia. The study found linguistic problems and organizational problems were among other problems of writing with the learners.

Furthermore, a large body of research (Ahn, 2012; Carstens, 2009; Chaisiri, 2010; Crossly, 2007; Elashri, 2013; Hyland, 2007; Lee, 2012; Liu, 2012; Luo \& Huong, 
2015; Reppen, 2002; Ting, Campbell, Law, \& Poh, 2013; Troyan, 2013) investigated the nature and effectiveness of genre-based pedagogies. While some researchers (Liu, 2012; Troyan, 2013; Luo \& Huong, 2015) explored genre analysis as a way of specifying the frequent patterns, structures, and moves shaping the distinct conventions of certain writing genres, others (Reppen, 2002; Carstens, 2009; Ting, Campbell, Law, \& Poh, 2013) were concerned with the explicit teaching of generic features and conventions of certain writing genres. A third party of researchers (Reppen, 2002; Ahn, 2012; Elashri, 2013) paid close attention to familiarizing learners with purposes of specific genres, particular audiences of the given genre, and the outcomes of writing in a certain genre.

In addition, developing descriptive writing stimulated Sujarwati (2005), Jeprianto (2011) and Rafika (2014). Sujarwati (2005) investigated the influence of using Whquestions on EFL students' writing skill. The result revealed that Wh-question strategy was effective in developing EFL students' descriptive writing performance. The same strategy was used by Jeprianto (2011) who investigated the effect of using Wh-questions on developing students' descriptive writing. Results revealed that using Whquestions enabled EFL students to generate ideas to write descriptive paragraphs. Rafika (2014) conducted a research on guided Wh-questions to teach descriptive writing. The researcher concluded that teaching descriptive text writing through Wh-questions was effective.

Focusing on the games for teaching descriptive writing, Rizki and Al-Hafizh (2013) used Catch-SpeakWrite (CSW) game for teaching descriptive text for senior high school students of the tenth grade. Results proved that the game developed students' writing descriptive performance. Along with gaming, Kartika and Saunir

\section{2}

Journal of Arabic Studies in Education \& Psychology(ASEP) 
(2013) investigated the effectiveness of the word Game on improving writing descriptive text at the junior high school. Results displayed that students' descriptive texts were improved because of using the Word Game.

In light of the previous literature review, it could be concluded that writing skill in EFL university context is a prerequisite for achieving EFL majors' academic assignments and passing their exams. However, EFL learners' writing performance is not up to the level required. In addition, the present study benefited from the previous literature review in conceptualizing writing genre, sensory descriptive writing and sensory vocabulary knowledge. Accordingly, the study variables were well grounded.

Similarly, previous research revealed that EFL learners' writing mistakes were almost the same in different EFL contexts. Additionally, while a large body of previous research focused on investigating the nature and effectiveness of genre based pedagogies, other studies were concerned with the explicit teaching of generic features and conventions of certain writing genres. Strikingly, few studies focused on EFL leaners' developing descriptive writing performance using Wh-questing strategy and gaming.

In view of all that has been mentioned so far, one may suppose that investigating the effectiveness of using senses in teaching/learning writing genres such as descriptive writing was left behind. In short, based on the insights gained from the previously mentioned review, it could be concluded that EFL learners' writing performance is not satisfactory. The literature on writing skill has highlighted several relevant topics such as senses pedagogy, genre writing and descriptive wring. Although extensive research has been carried out on writing skill in EFL 
context, no single study exists which couples senses to descriptive writing in EFL context at university level. Accordingly, the present study was designed to determine the effect of a suggested sensory based program on developing EFL university English majors' sensory vocabulary knowledge and descriptive writing performance.

\section{Method}

\subsection{Participants}

The study participants were 84 first year students majoring in English language at the Faculty of Education, October 6 University, Egypt. The participants were randomly divided into two equal groups. While the first group involved 42 students representing the control group, the second group comprised 42 students representing the experimental group. Before the intervention, all the participants were pretested by the Descriptive Writing Test (DWT) and the Sensory Vocabulary Knowledge Test (SVKT) that were prepared to obtain such required data. Pretesting revealed that the two groups were equal in terms of their descriptive writing performance and sensory vocabulary knowledge where the difference between the mean scores of the two groups were insignificant.

\subsection{Experimental Design}

The study used a pre-post-test experimental and control group design. Accordingly, before the intervention, the two groups were pre-tested. During the intervention, the experimental group participants were exposed to the suggested sensory based program in addition to their regular writing instruction. On the contrary, the control group students just received their regular writing instruction. After the intervention, the two groups were post-tested.

\subsection{Research Instruments}

\section{4}




\subsubsection{Sensory Vocabulary Knowledge Test (SVKT)}

\subsubsection{Aim of the SVKT}

The pre-post sensory vocabulary knowledge test (SVKT) was developed to measure EFL first year university English majors' sensory vocabulary knowledge. The test was prepared to achieve two objectives. Firstly, the test was used to pre-test the participants' sensory vocabulary knowledge to ensure that the equality of their performance before the intervention in the control group as well as the experimental group. Secondly, the same test was used to post-test the participants' sensory vocabulary knowledge after the intervention to decide the effectiveness of the proposed program.

\subsubsection{Content of the SVKT}

The content of the SVKT was prepared in light of the objectives and learning outcomes of the suggested program and the main principles of sensory vocabulary knowledge obtained from the review of the relevant literature. The test contained 5 questions. Question one required the test takers to find out 10 sensory descriptive words from a reading text prepared by the test maker to meet the test objectives. The second question asked the same test takers to define or explain the meaning of 20 sensory descriptive words. The third question required the same students to re-group or classify 25 sensory descriptive words according the five senses. According the intended task of the question four, the test takers were given 20 sensory descriptive words and were asked to identify their class or grammatical function. Finally, the fifth question asked the students to use given 10 sensory descriptive words in 10 sentences of their own (Appendix1).

\subsubsection{Validity of the SVKT}

\section{5}

Journal of Arabic Studies in Education \& Psychology(ASEP) 
The construct validity of the SVKT was determined by the same panel of TEFL experts who revised the proposed sensory program and the DWPT. Having the test amended in light of the experts' remarks, the final version of the test proved valid in terms of its aim, content and layout.

\subsubsection{Reliability of the SVKT}

As for the reliability of the SVKT, the test re-test procedure. The SVKT was administered to $20 \mathrm{EFL}$ first year university English majors who were excluded from participating in the main study experiment. After two weeks, the same test was re- administered to the same students. Then, students' scores on the first administration of the test were compared to their scores on the test readministered. The reliability coefficient for the test was ( $\mathrm{r}=$ 76). This value reveals that the test was reliability.

\subsubsection{Implementation of the SVKT}

Two days before beginning the intervention, the SVKT pre-test was administered to the participants. After the intervention, SVKT was administered to the participants as a post-test. Students' mean scores were calculated and compared using t-test.

\subsubsection{Scoring the SVKT}

The participants' vocabulary knowledge was scored according to a practical scoring measure that was one pint for each correct answer. The total test score was 85 points. Minor spelling mistakes were overlooked (Appendix 1).

\subsubsection{Descriptive Writing Performance Test (DWPT)}

\subsubsection{Aim of the DWPT}

The pre-post descriptive writing performance test (DWPT) was developed to measure EFL first year university English majors' descriptive writing performance.

\section{6}


The test was prepared to achieve two objectives. Firstly, the test was used to pretest the participants' descriptive writing performance to determine the equality and homogeneity of the two groups before the intervention. Secondly, the same test was used to posttest the participants' descriptive writing performance after the intervention to decide the effectiveness of the proposed program in developing the participants' descriptive writing performance.

\subsubsection{Content of the DWPT}

The content of the test was prepared in light of the objectives and learning outcomes of the suggested program and the main principles of descriptive writing gained from the review of the relevant literature. The test contained 2 parts. Part one included 5 questions. Each question required the test takers to write 5 paragraph of 5 sentences on topics of their own choice. The takers were asked to sensory descriptive words covering the 5 senses and descriptive writing rhetorical patterns. Part two involved one question requiring the test takers to write a descriptive essay of 20 sentences using sensory descriptive words covering the 5 senses and descriptive writing rhetorical patterns (Appendix 2).

\subsubsection{Validity of the DWPT}

The construct validity of the DWPT was determined by the same panel of TEFL experts who judged the proposed sensory program. Having the test modified in light of the experts' remarks, the final version of the test proved valid in terms of its aim, content and layout.

\subsubsection{Reliability of the DWPT}

As for the reliability of the DWPT, the test re-test procedure was used. The DWPT was administered to 20 EFL first year university English majors who were excluded from participating in the main study experiment. After two

\section{7}

Journal of Arabic Studies in Education \& Psychology(ASEP) 
weeks, the same test was re-administered to the same students. Then, students' scores on the first administration of the test were compared to their scores on the readministered test. The reliability coefficient for the test was $(\mathrm{r}=81)$. This value means that the test displayed reasonable reliability.

\subsubsection{Implementation of the DWPT}

A day before beginning the intervention, the DWPT pre-test was administered to the participants. After the intervention that lasted for 65 days, the DWPT was administered to the participants as a post-test. Students' mean scores were compared using t-test.

\subsubsection{Scoring the DWPT}

The participants' performance was scored according to a rubric of 5 evaluation indicators. The total test score was 45 marks/points. Five points was devoted to each paragraph and 20 points for the essay (Appendix 2).

\subsection{The Suggested Program}

Designing the suggested sensory based program went through several systematic procedural stages. The process of designing the suggested program started with stating its rational and ended with implementation.

\subsubsection{Program Rationale}

Firstly, the rationale of the suggested sensory program rested on four assumptions. According to Tilestone (2015), 98\% of all new learning enters the brain through the five senses. In addition, Truscott (2015) argues that second language inputs based on the senses is an essential aspect of language acquisition. Along with this point, Katai (2011) remarks that learning input by means of senses provides equality of opportunities for each student. To reiterate, Katai mentions sensory based learning helps "to recall the stored information easily in the future (p234)." Moreover,

\section{8}

Journal of Arabic Studies in Education \& Psychology(ASEP) 
Griva and Semoglou (2012) agree that activities which appeal to the five senses, such as visual, auditory, tactual and kinesthetic and hands-on activities have been reported to be the most effective teaching aids in English language classes.

Secondly, the teaching of descriptive writing in EFL context should make good use of the power of senses. In this respect, Bengu (2015, p 622) stated that "In fact, with descriptive writing you are not developing argument...You are representing the situation as it stands... The most characteristic features of descriptive writing are that it will describe something, but will not go beyond an account of what appears to be there." In practice, in descriptive writing, the writer uses sensory details such as sights, sounds, smells, tastes, feelings, and textures to create vivid images in the reader's mind. An experienced writer relies on sense memories of a specific experience to write a piece of descriptive writing.

Thirdly, whereas a large body of research on writing in EFL context has focused on developing EFL learners' general writing skills, developing specific writing genres was left behind.

Finally, like many other EFL learners in similar contexts, EFL university students' writing performance is not satisfactory. Therefore, designing a sensory based program seems to be a necessity for developing EFL university students' writing performance at the October 6 University.

\subsubsection{Program Aim}

The main aim of the suggested program is to develop EFL university students' sensory vocabulary knowledge and descriptive writing performance.

\subsubsection{Program Objectives}

\section{9}


By the end of the suggested program, EFL first year English majors, who successfully completed the program at October 6 University, will be able to:

1- Identify 20 sight words.

2- Classify 20 sight words according to their functions (v., n., adj., and adv.).

3- Use 20 sight words in correct descriptive sentences.

4- Identify 20 smell words.

5- Classify 20 smell words according to their functions (v., n., adj., and adv.).

6- Use 20 smell words in correct descriptive sentences.

7- Identify 20 taste words.

8- Classify 20 taste words according to their functions (v., n., adj., and adv.).

9- Use 20 taste words in correct descriptive sentences.

10- Identify 20 touch/texture words.

11- Classify 20 touch/texture words according to their functions (v., n., adj., and adv.)

12- Use 20 touch/texture words in correct descriptive sentences.

13- Identify 20 hearing words.

14- Classify 20 hearing words according to their functions (v., n., adj., and adv.)

15- Use 20 hearing words in correct descriptive sentences.

16- Write a descriptive paragraph of 5 sentences using sight descriptive words.

17- Write a descriptive paragraph of 5 sentences using smell descriptive words.

18- Write a descriptive paragraph of 5 sentences using taste descriptive words.

19- Write a descriptive paragraph of 5 sentences using touch descriptive words.

\section{0}


20- Write a descriptive paragraph of 5 sentences using hearing descriptive words.

21- Write a descriptive essay (of 20-25 sentences) using the five senses.

\subsubsection{Program Instructional Design}

Many instructional design models have been developed along the past two decades covering various educational settings. Suppasetseree (2005, p 18) states that "many models exist, ranging from simple to complex. All [models] provide a step-by-step guidance for developing instruction." To design the suggested program, a seven-step instructional design model was developed. The suggested model, partially, echoes some of the instructional design model of Brahmawong and Vate-U-Lan (2009).

1- Review of related body of knowledge through documentary research.

2- Develop the conceptual framework of the program.

3- Develop the first draft of the program.

4- Estimate the draft version of the program through a focus group.

5- Seek experts' verification of the suggested program.

6- Tryout the suggested program.

7- Revise and finalize the suggested program.

\subsubsection{Program Content}

In light of the 21 objectives of the suggested program, its content was designed and organized as follows (Student's Guide, Appendix: 3A):

\section{Part One: Sensory Vocabulary}

\section{Session I: Sight Description (50 minutes)}

Phase 1: Identifying sight words.

Phase 2: Classifying sight words according to their functions (v., n., adj., and adv.).

\section{1}


Phase 3: Using sight words in correct descriptive sentences.

\section{Session II: Smell Description (50 minutes)}

Phase 1: Identifying smell words.

Phase 2: Classifying smell words according to their functions (v., n., adj., and adv.).

Phase 3: Using smell words in correct descriptive sentences.

\section{Session III: Taste Description (50 minutes)}

Phase 1: Identifying taste words.

Phase 2: Classifying taste words according to their functions (v., n., adj., and adv.).

Phase 3: Using taste words in correct descriptive sentences.

\section{Session IV: Touch/texture Description (50 minutes)}

Phase 1: Identifying touch/texture words.

Phase 2: Classifying touch words according to their functions (v., n., adj., and adv.)

Phase 3: Using touch/texture words in correct descriptive sentences.

Session V: Hearing Description (50 minutes)

Phase 1: Identifying hearing words.

Phase 2: Classifying hearing words according to their functions (v., n., adj., and adv.)

Phase 3: Using hearing words in correct descriptive sentences.

\section{Part Two: Sensory Descriptive Writing}

Session I: Write a sight-based descriptive paragraph. (50 minutes)

\section{2}

Journal of Arabic Studies in Education \& Psychology(ASEP) 
Phase 1: Identifying the rhetorical patterns of a sightbased descriptive paragraph.

Phase 2: Pre-writing planning a sight-based descriptive paragraph.

Phase 3: Writing a sight-based descriptive paragraph.

Session II: Write a smell-based descriptive paragraph. (50 minutes)

Phase 1: Identifying the rhetorical patterns of a smellbased descriptive paragraph.

Phase 2: Pre-writing planning a smell-based descriptive paragraph.

Phase 3: Writing a smell-based descriptive paragraph.

Session III: Write a taste-based descriptive paragraph. (50 minutes)

Phase 1: Identifying the rhetorical patterns of a tastebased descriptive paragraph.

Phase 2: Pre-writing planning a taste-based descriptive paragraph.

Phase 3: Writing a taste-based descriptive paragraph.

Session IV: Write a touch-based descriptive paragraph. (50 minutes)

Phase 1: Identifying the rhetorical patterns of a touchbased descriptive paragraph.

Phase 2: Pre-writing planning a touch-based descriptive paragraph.

Phase 3: Writing a touch-based descriptive paragraph.

Session V: Write a hearing-based descriptive paragraph. (50 minutes)

Phase 1: Identifying the rhetorical patterns of a hearingbased descriptive paragraph.

\section{3}

Journal of Arabic Studies in Education \& Psychology(ASEP) 
Phase 2: Pre-writing planning a hearing-based descriptive paragraph.

Phase 3: Writing a hearing-based descriptive paragraph.

Session VI: Write a descriptive essay integrating the five senses. (50 minutes)

Phase 1: Identifying the rhetorical patterns of a descriptive essay.

Phase 2: Pre-writing planning a descriptive essay.

Phase 3: Writing a descriptive essay.

\subsubsection{Program Teaching Approach}

While the eclectic teaching approach was adopted for teaching the suggested program, the outcome-based teaching and learning approach was the leading teaching approach. The outcome-based teaching and learning approach is a pedagogical process which focuses on the achievement of certain specified results. Pang (2009, p122) mentions that "outcome-based therefore, is concerned with curriculum design and ensuring that the contents, delivery, activities, and assessments are all aligned to help facilitate students to attain specific intended learning outcomes." For more details see (Teacher's Guide, Appendix: 3B).

\section{Phase: I}

The teacher/researcher explains the objectives of the session to the students and directs their attention to the targeted learning outcomes. Then, the teacher/researcher presents the content materials using proper learning aids and activities.

\section{Phase: II}

The teacher/researcher re-explains the content materials allowing the students chance to practice the focal points using individually and in groups. Providing students with performance model is a must.

\section{4}




\section{Phase: III}

The teacher/researcher leaves the floor to the students to produce the intended learning outcomes. In this phase, students' performance is subject to be monitored, guided and evaluated by the teacher/researcher. Finally, the teacher/researcher has to wrap up and resolve all the problematic point that students faced.

\subsubsection{Program Evaluation}

The program learning outcomes were subject to formative and summative evaluation procedures. (Appendices: 3 A \& B).

\subsubsection{Program Feasibility}

Having the draft version of the program prepared, it was sent 7 EFL professors and experts. Experts' remarks refined some of its components. For example, the program objectives were 25 in the draft version and reduced to be 21 in final version. Writing a descriptive essay integrating the five senses was added to the final version of the program content. Finally, the final version was sent to the same EFL jury members who approved its feasibility in terms of its objectives and content.

\section{Results and Discussion}

\subsection{Results of the Sensory Vocabulary Knowledge Test} (SVKT)

Table 1: Differences between the mean scores of the experimental group and the control group on the Pre-Sensory Vocabulary Knowledge Test

\begin{tabular}{|c|c|c|c|c|c|c|c|}
\hline & & & & & & & \\
\hline Pre /Group & $\mathbf{N}$ & Mean & SD & $d f$ & $t$ & $p$ & Sig. \\
\hline Experimental & 42 & 31.76 & 10.52 & 82 & 0.5194 & 0.6049 & Insignificant \\
\hline Control & 42 & 30.57 & 10.49 & & & & \\
\hline
\end{tabular}

Table 1 shows that the mean scores of the experimental group $(m=31.76)$ looks a lot like the mean

\section{5}

Journal of Arabic Studies in Education \& Psychology(ASEP) 
scores of the control group $(\mathrm{m}=30.57)$ on the pre Sensory Vocabulary Knowledge Test (Pre-SVK). The difference between mean scores of the experimental group minus the mean scores of the control group equals 1.19. According to the t-test results, the difference between the two mean scores is statistically insignificant where the calculated $t$ is (0.5194) and the $\mathrm{p}$ value is (0.6049). By conventional criteria, this difference $(\mathrm{P}=0.6049)$ is considered to be not statistically significant at $95 \%$ confidence interval.

The result reveals that the two groups are equal in terms the participants' sensory vocabulary knowledge assuring that the homogeneity of the selected sample. In light of the above statistically sustained result, the study first hypothesis was accepted as it was stated: There is no statistically significant differences between the mean scores of the control group students and the experimental group participants on the pre-SVKT. Collectively, the low mean scores of the experimental group (31.76) and that of the control group (30.57) on the pre-SVKT were beyond the success score level 51 (60\% of the max test score 85).

Sensibly, such result seems logical since the two groups did not receive any previous formal instruction pertinent to the content of the Sensory Vocabulary Knowledge Test. It seems possible that these results are due to the claim that most of secondary school students' vocabulary knowledge is fragile because they used to resort to exam oriented instruction in private tutoring centers. In this respect, recent research indicates that vocabulary instruction may be problematic because many teachers are not "confident about best practice in vocabulary instruction and at times don't know where to begin to form an instructional emphasis on word learning" (Berne \& Blachowicz, 2008, p. 315). 
Table 2: Differences between the mean scores of the experimental and control groups on the Post- Sensory Vocabulary Knowledge Test (SVKT)

\begin{tabular}{|c|c|c|c|c|c|c|c|}
\hline Group & $\mathbf{N}$ & Mean & SD & $d f$ & $t$ & $\vec{p}$ & Sig. \\
\hline Post- Experimental & 42 & 74.60 & 4.68 & & & & \\
\hline & & & & 82 & 13.89 & $\begin{array}{l}<0.000 \\
1\end{array}$ & $\begin{array}{l}\text { Significan } \\
\mathbf{t}\end{array}$ \\
\hline Post-Control & 42 & 30.88 & 4.14 & & & & \\
\hline
\end{tabular}

Table 2 displays that the mean scores of the experimental group on the Post- SVKT (74.60) is exceptionally higher than the mean scores of the control group (30.88) on the post Sensory Vocabulary Knowledge Test. By conventional criteria, since the $t$ value was 33.18 and the two-tailed $\mathrm{P}$ value was less than 0.0001 , this difference is statistically significant. Conventionally, the difference between the two mean scores is considered to be statistically significant at $95 \%$ confidence interval. Statistically, the second hypothesis was accepted as it was stated: There is a statistically significant difference between the mean scores of the control group students and the experimental group participants on the post-SVKT favoring the experimental group participants.

The observed increase in of the mean scores of the experimental group on the Post- SVKT (74.60) could be attributed to the effectiveness of the sensory based program in developing EFL students' sensory vocabulary knowledge. It may be that the proposed program was more effective than regular writing classes in developing EFL students' sensory vocabulary knowledge. Collectively, the high mean scores of the experimental group 74.60 exceeded the success score level 51 (60\% of the max test score 85$)$ on the post-SVKT. Wisely, such result seems logical since the two groups received two different types of inputs. EFL students' sensory vocabulary knowledge in the experimental group was improved because they exposed to innovative inputs such as using pictures and You Tube. This result is partially in line with the main finding of Gutiérrez, Puello, and Galvis (2015) who found that pictures helped EFL students increase their vocabulary usage. 
Table 3: Differences between the mean scores of the experimental group on the Pre and Post Sensory Vocabulary Knowledge Test (SVKT)

\begin{tabular}{|c|c|c|c|c|c|c|c|}
\hline Group & $\mathbf{N}$ & Mean & SD & $d f$ & $t$ & $p$ & Sig. \\
\hline Pre- Experimental & 42 & 31.76 & $\begin{array}{c}10.5 \\
2\end{array}$ & 82 & $\begin{array}{l}24.11 \\
7\end{array}$ & $\begin{array}{l}<0.000 \\
1\end{array}$ & $\begin{array}{l}\text { Significan } \\
\mathrm{t}\end{array}$ \\
\hline Post-Experimental & 42 & 74.60 & 4.68 & & & & \\
\hline
\end{tabular}

Table 3 displays that the mean scores of the participants of the experimental group on the Post- SVKT (74.60) is exceptionally higher than their mean scores of the Pre-SVKT (31.76). The difference between mean scores of the experimental group on the post-SVKT minus their mean scores on the pre-SVKT equals 32. By conventional criteria, when the $t$ value is 24.117 and the two-tailed $\mathrm{P}$ value was less than 0.0001, the difference is statistically significant. Conventionally, the difference between the two mean scores is considered to be statistically significant at 95\% confidence interval. Statistically, the third hypothesis was accepted as it was stated: There is a statistically significant difference between the mean scores of the experimental group participants' mean scores on the preSVKT and post-SVKT favoring their mean scores on the post-SVKT.

The increase of the mean scores of the experimental group on the Post- SVKT (74.60) could be attributed to the effectiveness of the sensory based program in developing EFL students' sensory vocabulary knowledge. It may be that the proposed program was more effective than regular writing classes in developing EFL students' sensory vocabulary knowledge.

\section{Program Effect Size / Sensory Vocabulary Knowledge (SVK)}

To estimate the effective size of the suggested program on developing EFL English majors' sensory vocabulary knowledge (SVK), Black's modified gain ratio was used as follows:

\section{8}




$$
\text { Black Modified Gain Ratio }=\frac{\bar{Y}-\bar{X}}{\mathrm{~T}-\overline{\mathrm{X}}}+\frac{\overline{\mathrm{Y}}-\overline{\mathrm{X}}}{\mathrm{T}}
$$

- $\mathrm{Y}=$ Mean of scores for the post test for the experimental group students;

- $\mathrm{X}=$ Mean of scores for the pre-test for the

experimental group students;

- $\mathrm{T}=$ Total score in the test.

- Blake's registered max. Value= 2 .

- Accepted Value starts at 1.2.

$$
\text { Black MGR }=\frac{74.60-31.76}{85-31.76}+\frac{74.60-31.76}{85}=1.43
$$

Table 4: Program Effect Size on developing EFL majors'SVK (Black

\begin{tabular}{ccccc}
\multicolumn{4}{c}{$M G R)$} \\
\hline$\Sigma$ Test Score & $\begin{array}{c}\text { Pre-test } \\
\text { Mean }\end{array}$ & $\begin{array}{c}\text { Post-test } \\
\text { Mean }\end{array}$ & $\begin{array}{c}\text { M. Gain } \\
\text { Ratio }\end{array}$ & Sig. \\
\hline $\mathbf{8 5}$ & $\mathbf{3 1 . 7 6}$ & $\mathbf{7 4 . 6 0}$ & $\mathbf{1 . 4 3}$ & $\begin{array}{c}\text { Accepted: Above } \\
\mathbf{1 . 2}\end{array}$ \\
\hline
\end{tabular}

The above table shows that the suggested sensory was effective in achieving its aims since the gain ration 1.43 is higher than 1.2. Accordingly, the third hypothesis was reaccepted as it was stated: There is a statistically significant difference between the mean scores of the experimental group participants' mean scores on the pre-SVKT and postSVKT favoring their mean scores on the post-SVKT.

\subsection{Results of the Descriptive Writing Performance Test (DWPT)}

Table 5: Differences between the mean scores of the experimental group and the control group on the Pre-Descriptive Writing Performance Test (DWPT)

\begin{tabular}{lcccccc|c}
\hline Group & $\mathrm{N}$ & Mean & SD & $d f$ & $t$ & $p$ & Sig. \\
\hline Pre Experimental & 42 & 15.64 & 3.65 & & & & \multirow{2}{*}{ Insignificant } \\
Pre Control & 42 & 14.29 & 2.99 & & & & \\
\hline
\end{tabular}

Table 5 shows that the mean scores of the experimental group (15.64) seems similar the mean scores

\section{9}

Journal of Arabic Studies in Education \& Psychology(ASEP) 
of the control group (14.29) on the Pre- Descriptive Writing Performance Test (DWPT). According to the t-test results, the difference between the two mean scores is statistically insignificant where the $t$ value is (0.8846) and the $p$ value is (0.0658). By conventional criteria, this difference $(\mathrm{P}=0.0658)$ is considered to be not statistically significant at 95\% confidence interval.

The result reveals that the two groups are equal in terms the participants' descriptive writing performance assuring that the homogeneity of the selected sample. In light of the above statistically result, the study fourth hypothesis was accepted as it was stated: There is no statistically significant differences between the mean scores of the control group students and the experimental group participants on the pre-DWPT.

Collectively, the low mean scores of the experimental group (15.64) and that of the control group (14.29) on the pre-DWPT were beyond the success score level 27 (60\% of the max test score 45). Seemingly, such scores reveal that most of the EFL first year English majors' writing performance was not up to the required level. Rationally, such result seems logical since the two groups did not receive any previous formal instruction pertinent to the content of the DWPT. It seems possible that these results are due to the claim that most of the secondary school students used to resort to exam oriented instruction in private tutoring centers. Practically, they were given no chance to learn genre writing as it was not included secondary school English language learning objectives.

Table 6: Differences between the mean scores of the experimental group and the control group on the Post-Descriptive Writing Performance Test

(DWPT)

\begin{tabular}{lcccccc|c}
\hline Group & N & Mean & SD & $d f$ & $t$ & $p$ & Sig. \\
\hline Post- Experimental & 42 & 30.38 & 4.04 & & & & \\
& & & & 82 & 21.86 & $<0.000$ & Significan \\
Post-Control & 42 & 18.31 & 4.39 & & & & t \\
\hline
\end{tabular}


As displayed in Table 6, the mean scores of the experimental group (30.38) is exceptionally higher than the mean scores of the control group (18.31) on the post Descriptive Writing Performance Test (DWPT). The difference between the two mean scores is statistically significant where the calculated $t$ value is (21.865) and the $P$ value is less than (0.0001). Accordingly, the fifth hypothesis was accepted as it was stated as follows: There is a statistically significant difference between the mean scores of the control group students and the experimental group participants on the post-DWPT favoring the experimental group participants. Consequently, the sensory based program was more effective than regular writing classes in developing EFL students' descriptive writing performance.

Moreover, utilizing pictures and videos for training EFL students on using their senses (Sight, Sound, Smell, Taste, and Touch) was an easy task for most of the participants to develop their overall performance of descriptive writing. To this point, Axelrod and Cooper (2001) confirmed that sensory details were important to create descriptive images that enable learners to bring the words on the page to life and in turn their descriptive paragraph writing was improved. For more supporting evidence, Youra (2009) developed a writing and photography project for EFL students and concluded that photography was an encouraging aid for students to explore new possibilities in their descriptive writing. Partially, this finding was in line with the finding of Jarunthawatcha (2010) who determined that the process-genre approach helped the students to perform better in writing descriptive compositions.

Table 7: Differences between the mean scores of the experimental group on the pre and post Descriptive Writing Performance Test (DWPT)

\begin{tabular}{|c|c|c|c|c|c|c|c|}
\hline Group & $\mathbf{N}$ & Mean & SD & $d f$ & $t$ & $p$ & Sig. \\
\hline Pre- Experimental & 42 & 15.64 & 3.64 & 82 & 27.14 & $<0.000$ & Significan \\
\hline Post-Experimental & 42 & 38.45 & 3.65 & & & & \\
\hline
\end{tabular}

\section{1}

Journal of Arabic Studies in Education \& Psychology(ASEP) 
As shown in Table 7, the mean scores of the experimental group on the Post-DWPT (38.45) is higher than their mean scores on the Pre-DWPT (15.64). The difference between the two mean scores is statistically significant where the calculated t value is (27.143) and the $\mathrm{P}$ value is less than (0.0001). Accordingly, the sixth hypothesis was accepted as it was stated as follows: There is a statistically significant difference between the mean scores of the experimental group participants' mean scores on the pre-DWPT and their mean score on the post-DWPT favoring their mean scores on the post-DWPT. Such a result confirms that the sensory based program was effective in developing EFL students' descriptive writing performance. Obviously, this result is similar to the result shown in Table 6 where the two results confirm the effectiveness of the sensory based program in developing EFL students' descriptive writing performance.

\section{Program Effect Size / Descriptive Writing Performance (DWP)}

To estimate the effective size of the suggested program on developing EFL English majors'DWP, Black's modified gain ratio was used as follows:

$$
\text { Black Modified Gain Ratio }=\frac{\bar{Y}-\bar{X}}{\mathrm{~T}-\overline{\mathrm{X}}}+\frac{\overline{\mathrm{Y}}-\overline{\mathrm{X}}}{\mathrm{T}}
$$

- $\mathrm{Y}=$ Mean of scores for the post test for the experimental group students;

- $\mathrm{X}=$ Mean of scores for the pre-test for the experimental group students;

- $\mathrm{T}=$ Total score in the test.

- Blake's registered max. Value $=2$.

- Accepted Value starts at 1.2.

Black MGR $=\frac{38.45-15.64}{45-15.64}+\frac{38.45-15.65}{45}=1.34$ 
Number 71, Part 2, March , 2016

Table 8: Program Effect Size on developing EFL majors' DWP

\begin{tabular}{ccccc}
\hline$\Sigma$ Test Score & $\begin{array}{c}\text { Pre-test } \\
\text { Mean }\end{array}$ & $\begin{array}{c}\text { Post-test } \\
\text { Mean }\end{array}$ & $\begin{array}{c}\text { M. Gain } \\
\text { Ratio }\end{array}$ & Sig. \\
\hline 45 & 13.75 & 35.07 & 1.34 & $\begin{array}{c}\text { Accepted: Above } \\
1.2\end{array}$ \\
\hline
\end{tabular}

The above table shows that the suggested sensory was effective in achieving its aims since the gain ration 1.34 is higher than 1.2. Accordingly, the sixth hypothesis was reaccepted as it was stated: There is a statistically significant difference between the mean scores of the experimental group participants' mean scores on the pre-DWPT and their mean score on the post-DWPT favoring their mean scores on the post-DWPT.

\section{Study Conclusion}

The study attempts to investigate the effectiveness of a suggested sensory based program in developing first year university EFL majors' sensory vocabulary knowledge and descriptive writing performance. Results revealed that the sensory based program was more effective than regular writing classes in developing EFL students' sensory vocabulary knowledge and descriptive writing performance.

The findings of this study indicate that the suggested sensory based program was effective in developing first year university EFL majors' sensory vocabulary knowledge and descriptive writing performance. That is to say, the suggested sensory based program could be a promising intervention innovation in the context of developing sensory vocabulary knowledge and descriptive writing performance in EFL context. Empirically, experimental group students were able to use sensory vocabulary and apply descriptive writing conventions, whereas the control group participants were not able to produce the same performance.

Based on the study results, sensory based programs should be adopted to teach writing genre in EFL context. More training sessions are required to train EFL college English majors on utilizing writing genre rhetorical patterns.

\section{3}


More training sessions are required to train EFL College writing teaching assistants on utilizing senses and sensory details. College writing courses should be carefully selected or rather should be carefully designed. In addition, more research should be carried out using sensory based programs in developing other writing genres.

\section{References}

Ahn, H. (2012). Teaching writing skills based on a genre approach to L2 primary school students: An action research. English Language Teaching, 5(2), 2-16.

Al Fadda, H. (2012). Difficulties in academic writing: From the perspective of King Saud University postgraduate students. English Language Teaching, $5(3), 123-131$.

Al Seyabi, F., \& Tuzlukova, V. (2014). Writing problems and strategies: An investigative study in the Omani school and university context. Asian Journal of Social Sciences \& Humanities, 3(4), 37-48.

Alagozlu, N. (2007). Critical Thinking and Voice in EFL Writing. Asian EFL Journal, 9(3), 118-136.

Al-Khairy, M. A. (2013). Saudi English-major undergraduates' academic writing problems: Taif University perspective. English Language Teaching, 6(6),

Alwasilah, A. C. (2001). Developing theories of teaching academic Indonesian to non-language majors: ways of collecting and analyzing the data. http://www.fp.utm.my/ epusatsumber/ listseminar/7.

Badger, R. G. \& White, G., 2000. A Process Genre Approach to Teaching Writing. ELT Journal, 54(2), 153-160.

Bengu Aksu Atac (2015). From descriptive to critical writing: A study on the effectiveness of advanced reading and writing instruction. Procedia Social and Behavioral Sciences 199, 620 - 626.

Berne, J. I., \& Blachowicz, C. L. (2008).What reading teachers say about vocabulary instruction: Voices from the classroom. The Reading Teacher, 62(4), 314-323

Brahmawong, C. and P. Vate-U-Lan (2009). Guidelines for PhD Research Actions, Assumption University of Thailand.

Brown, H. D. (2007). Principles of language learning and teaching. White Plains: Pearson Education.

Carstens, A. (2009). The effectiveness of genre-based approaches in teaching academic writing: Subject-specific versus cross-disciplinary emphases. Unpublished doctoral dissertation, Pretoria, South Africa, University of Pretoria.

Chaisiri, T. (2010). Implementing a genre pedagogy to the teaching of writing in a university context in Thailand. Language Education in Asia, 1(1), 181-199.

\section{4}


Chakraverty, A., \& Gautum, K. K. (2008). Dynamics of writing. In P. Shankar (Ed.), Teaching of English (pp. 286-297). New Delhi: APH.

Cheng, F. W. (2005). Audience strategies used by EFL college writers. Journal of Pan-Pacific Association of Applied Linguistics (PAAL), 9(2), 209-225.

Christie Frances dan J. R. Martin. (2000). Genre and Institutions: Social Process in the Workplace and School. New York: Continum.

Cope, B. \&Kalantzis, M. (eds.) (2012). The Powers of Literacy: A Genre Approach to Teaching Writing. New York: Routledge.

Crossly, S. (2007). A chronotopic approach to genre analysis: An exploratory study. English for Specific Purposes, 26, 4-24.

Deporter, B., \& Heracky, M. (2002). Quantum Learning. Bandung: Penerbit Kaifa.

Elashri, I. I. (2013). The effect of the genre-based approach to teaching writing on the EFL Al-Azhar secondary students' writing skills and their attitudes towards writing. Retrieved March 8, 2014, from files.eric.ed.gov/fulltext/ED539137.pdf

Evans, P. (2013). How to teach non-fiction writing at key stage 3. New York: Routledge.

Farooq, M. S., Uzair-Ul-Hassan, M., \& Wahid, S. (2012). Opinion of second language learners about writing difficulties in English language. South Asian Studies, 27(1), 183-196.

Fitri Purnama Sari (2013). An analysis on students' ability and problems in writing recount texts at grade VIII at SMPN 29 Padang. Journal of English language teaching. 2(1), 73-85.

Fusillo,A.(2000).Imaginative writer.Australia: Curriculum Cooperation.

Gass, S. (1999). Incidental vocabulary learning. SSLA, 21, 319-333.

Gathercole,S.(2006).Complexities and constraints in non-word repetition and word learning.Applied Psycholinguistics, 27(4),513-543.

Glencoe, N. (2005). Writer's choice: Grammar and composition. New York: McGraw Hill.

Griva, E., \& Semoglou, K. (2012). Estimating the effectiveness and feasibility of a game-based project for early foreign language learning. English Language Teaching, 5(9), 33-44.

Gutierrez, K., Puello, N \& Galvis, L. (2015). Using Pictures Series Technique to Enhance Narrative Writing among Ninth Grade Students at Institución Educativa Simón Araujo. English Language Teaching, 8(5).

Hadfield, Jill (2008). Introduction to Teaching English. Oxford Basics: Oxford University Press.

Harmer, J. (2004). How to teach writing. Essex: Pearson Education.

Harmer,Jeremy.(2007).How to teachEnglish.Harlow:Pearson Longman.

Harmon, J. M., Wood, K. D., \& Kiser, K. (2009). Promoting vocabulary learning with the interactive word wall. Middle School Journal, 40(3), $58-63$.

Hiew, W. (2012). English language teaching and learning issues in Malaysia: Learners' perceptions via Facebook dialogue journal. Journal of Arts, Science \& Commerce 3(1): 11-19.

\section{5}


Hosenni, M., Taghizedeh, M. E., Abedin, M. J. Z \& Naseri, E. (2013). The importance of EFL learners' writing skill: Is there any relationship between writing skill and content score of English Essay Test? International Letters of Social and Humanistic Sciences, 6, 1-12.

Hosking, R. (2014). Why good essay writing skills are important in today's workplace. Retrieved from executive secretary.com on 4th February, 2015.

Hussin, S., Abdullah, M. Y., Ismail, N., \& Yoke, S. K. (2015). The Effects of CMC Applications on ESL Writing Anxiety among Postgraduate Learners. English Language Teaching, 8(9), 167-172.

Hyland, K. (2003). Second Language Writing. London: Cambridge University Press.

Hyland, K. (2007). Genre pedagogy: language, literacy and L2 writing instruction.Journal of Second Language Writing.16(3),148-164.

Jarunthawatcha, W. (2010). A Process-Genre Approach to Teaching Second Language Writing: Theoretical Perspective and Implementation in a Thai University Setting. $\mathrm{PhD}$ Thesis, University of Southampton.

Javid, C.Z., Farooq, U., \& Umer, M. (2013). An Investigation of Saudi EFL learners' Writing Problems: A Case Study along Gender-lines. Kashmir Journal of Language Research, AJK University, 16(1), 179-203.

Jeprianto, P. (2011). The Use of Wh-Question Technique in Teaching Recount Text. Jakarta: Universitas Negeri Gorontalo.

Kartika, Widya and Saunir, Saun (2013). Using one word-two-three word game in teaching writing a descriptive text. Journal of English language teaching, 1(2), 87-96.

Katai, Z. (2011). Multi-sensory method for teaching-learning recursion. Computer Applications in Engineering Education, 19(2), 234-243.

Kellogg,R.T.(2008).Training writingskills:ACognitive Developmental Perspective. Journal of Writing Research, 1(1), 1-26.

Kim, M. (2006). Genre-based approach to teaching writing. The Hawaii Pacific University TESOL Working Paper Series, vol. 4(2), 33-39.

Kitchakarn, O. (2012). Incorporating Peer Response to Writing Process. Executive Journal, Bangkok University 32 (3), 70-76.

Kongpetch, S. (2006). Using a genre-based approach to teach writing to Thai students: a case study. Prospect, 21(2), 3-33.

Kroll, B., Diaz-Rico, L. \& Weed, K., 2002. The Cross-Cultural, Language, and Academic Handbook: A Complete K-12 Reference Guide, Boston: Allyn and Bacon.

Lee, M. (2012). Teaching genre-based writing to Korean high school students at a basic level. Unpublished master's thesis, University of Wisconsin River Falls.

Liu, F. (2012). Genre analysis of American presidential inaugural speech. Theory and Practice in Language Studies, 2(11), 2407-2411.

Luo, J.,\&Huang,T.Y.(2015).Genre-based analysis of American tourism brochures.Open Journal of Social Sciences,3,200-208. 
Martin, J. R. \& Rose, D. (2012). Learning to Write/Learning to Learn: Genre, Knowledge and Pedagogy in the Sydney School. London: Equinox.

Mason, L. H., Harris, K. R., \& Graham, S. (2011). Self-regulated strategy development for students with writing difficulties. Theory into Practice, 50(1), 20-27.

Mustaque, S. (2014). Writing problems among the tertiary level students in Bangladesh: A study in Chittagong Region. Language in India, 14(1), 6284.

Myles, J. (2002). Second language writing and research: the writing process and error analysis in students' texts. Journal TESEL-EJ. 6(2), 146-148.

Nagy, W. E. (2005). Why Vocabulary Instruction Needs to Be Long-Term and Comprehensive. In E.H. Hiebert \& M.L. Kamil (Eds.), Teaching and learning vocabulary; Bringing research to practice, (pp. 27-44). Mahwah, New Jersey: Lawrence Erlbaum Associates.

Nation, I. S. P. (2001). Learning vocabulary in another language. Cambridge: Cambridge University Press.

Nation, I. S. P. (2011). Learning vocabulary in another language. Cambridge: Cambridge University Press.

Nazario, L., Borchers, D., \& Lewis, W. (2010). Bridges to better writing. Boston, MA: Wadsworth Cengage Learning.

Pang, Mary (2009). Learning approaches and outcome-based teaching and learning: A case study in Hong Kong, China. Journal of Teaching in International Business, 20(2), 106-122.

Pike, M. (2013). Teaching secondary English. Thousand oaks, California: Sage Publications.

Pikulski,J.J.,\&Templeton,S.(2004).Teaching and developing vocabu- lary:Key long term reading success. HoughtonMifflin Reading.

Rafika, M. (2014). Teaching descriptive text writing through guided Whquestions: A pre-experiment student at the eighth grade students of SMP Negeri 7 Pontianak in Academic Year 2013/2014. WKS: Studies on English Language and Education, 1(1), 51-58.

Raoofi, S., Chan, S. H., Mukundan, J., \& Rashid, S. M. (2014). A Qualitative Study into L2 Writing Strategies of University Learners. English Language Teaching, 7(11), 39-45.

Reppen, R. (1995). A genre-based approach to content writing instructions. TESOL Journal, 4, 32-35.

Reppen, R. (2002). A genre-Based approach to content writing instruction. In J. C. Richards \& W. A. Renandya (Eds.), Methodology in language teaching: An anthology of current practice (pp.321327).Cambridge:Cambridge University Press.

Rizki Annisa and Al-Hafizh, Muhd.(2013).Teaching writing a descriptive text to senior high school students by using the CSW game. Journal of English language teaching, 1(2), 78-86.

Rozmiarck, R. (2000). Descriptive Writing. Westminster, CA: Teachers Created Recourses. 
Scott Rebecca dan Avery Simon (eds). (2001). Writing With Style. London: Pearson Education Limited.

Sujarwati, I. (2005). The Influence of using Wh-questions as teaching guidance toward the students' ability in writing recount text. Journal of Education, 5(1), 122-136.

Sumarsih, M. P., \& Sanjaya, D. (2013). TPS as an Effective Technique to Enhance the Students' Achievement on Writing Descriptive Text. English Language Teaching, 6(12), 106-121

Syahputra Adhe, Ardi Havid (2013). The implementation of CmapTools program in teaching descriptive text to junior high school. Journal of English language teaching, 1(2), 60-69.

Tardy,C.M.(2011). The history and future of genre in second language writing. Journal of Second Language Writing, 20(1), 1-5.

Taufiq H., Sofyan A., and Syamsul B. (2016): Improving the students' ability in writing descriptive paragraph by using questioning techniques. Proceedings of the First Reciprocal Graduate Research Symposium between University Pendidikan Sultan Idris and Syiah Kuala University, Malaysia.74-90.

Thoreau, M. (2006). Write on Track. New Zealand: Pearson Education New Zealand.

Tilestone, D. W. (2011). Ten best teaching practices: how brain research, learning styles, and standards define teaching competences. USA: Corwin Press Inc.

Ting,S.H.,Campbell,Y.M.,Law,L.\&Poh,H.H.(2013).Explanationswithout a purpose? Genre-based instruction and academic writing. Journal of Academic Language \& Learning,7(1),26-39.

Troyan, F. J. (2013). Investigating a genre-based approach to writing in an elementary Spanish program. Unpublished doctoral dissertation, Pennsylvania: University of Pittsburg.

Truscott, J. (2015). Consciousness and Second Language Learning. BristolBuffalo-Toronto: Multilingual Matters.

Wang, Y. (2004). English magazines: Motivation improved EFL writing skill. English Teaching Forum, 42(1), 24-29.

Wennerstrom, A. (2003). Discourse Analysis in the Language Classroom. Vol. 2. Genres of Writing. Michigan: The University of Michigan Press.

Widodo, H. P. (2006). Designing a genre-based lesson plan for an academic writing course. English Teaching: Practice \& Critique, 5(3), 173-199.

Yuen, C. \& Mussa, I. (2015). Academic writing difficulties of Iraqi postgraduate students in Malaysia. International Journal of Education and Research, 3(6), 25-34.

Zahedi, Y., \& Abdi, M. (2012). The effect of semantic mapping strategy on EFL learners' vocabulary learning. Procedia Social and Behavioral Sciences, 69, 2273-2280.

溇溇溇溇溇 